\title{
KUALITAS PUPUK ORGANIK LIMBAH AMPAS KELAPA DAN KOPI TERHADAP PERTUMBUHAN TANAMAN
}

\author{
Dipta Adi H, Cuti Winarti,Warsiyah \\ Progam Studi Teknik Lingkungan Institut Teknologi Yogyakarta
}

\begin{abstract}
ABSTRAK
Ampas kopi dan ampas kelapa masih menjadi limbah padat yang sering dibuang di lingkungan tanpa diolah. Di daerah Yogyakarta, banyak kedai kopi dengan sengaja membuang ampas kopi begitu saja ke tempat sampah. Ampas kelapa juga masih sering dianggap kurang bermanfaat bagi sebagian pihak dari industri minyak yang hanya menggunakan daging kelapa parutnya saja. Namun disisi lain sebenarnya banyak kandungan nutrisi yang dapat dimanfaatkan dari ampas kopi dan ampas kelapa, dan juga dapat mengurangi limbah padat di lingkungan.

Penelitian dilakukan dengan cara mengolah ampas kopi dan ampas kelapa menjadi pupuk organik. Pupuk organik dibuat 2 macam yaitu pupuk A dengan kadar ampas kelapa 200 gram dan pupuk B dengan kadar ampas kelapa 300 gram. Proses pembuatan pupuk dibutuhkan waktu selama 3 minggu. Dilanjutkan dengan proses pemberian pupuk organik ke tanaman tomat. Pada penelitian ini menggunakan 7 perlakuan yaitu Po (Kontrol), Pa, Pb, Pc, Pd, Pe dan Pf. Setiap perlakuan diamati pertumbuhan tinggi tanamannya setiap minggu selama 3 minggu.

Berdasarkan dari hasil penelitian ini menunjukkan bahwa kandungan pada pupuk A yaitu $1,119 \% \mathrm{~N}, 1,748 \% \mathrm{P}$, dan $1,19 \% \mathrm{~K}$ dan kandungan pupuk $\mathrm{B}$ sebesar $1,035 \% \mathrm{~N}, 1,873 \% \mathrm{P}$, dan $1,15 \% \mathrm{~K}$. Pertumbuhan tanaman tomat yang telah diamati setiap minggu menunjukkan bahwa pemberian pupuk organik dari ampas kopi dan ampas kelapa menunjukkan perbedaan yang sangat nyata terhadap pertumbuhan tanaman. Tinggi tanaman paling rendah adalah Po karena merupakan perlakuan pada tanaman tomat yang tidak diberi pupuk organik. Varian pemberian pupuk organik dari ampas kopi dan ampas kelapa paling efektif adalah perlakuan $\mathrm{Pb}$ dengan pemberian 150 gram pupuk pada media tanam $1 \mathrm{~kg}$.
\end{abstract}

Kata kunci : Kualitas, Pupuk Organik, Ampas Kopi dan Ampas Kelap

\section{QUALITY OF ORGANIC FERTILIZER FOR COCONUT COFFEE AND COFFEE WASTE ON PLANT GROWTH}

\footnotetext{
ABSTRACT

Coffe and coconut dregs is still to be solid waste which is throw away unprocessed. There are a lot of coffee shop in Yogyakarta who throw away the coffee dregs unprocessed on the trash can. Coconut dregs is not useful for some of peoples from oil industry who only use grated coconut product. But in other side coffe and coconut dregs is contains a lot of nutrient contain which is useful and can decrease solid waste in the environtment.

This research tell about how to process coffe and coconut dregs become organic fertilizer. There are 2 kinds of fertilizer such as Fertilizer A is contains 200 gram coconut dregs and fertilizer $B$ is contains 300 gram of coconut dregs. It need 3 weeks to process the fertilizer. After that put organic fertilizer to tomato tree. This research use 7 treatments such as Po (control), $\mathrm{Pa}, \mathrm{Pb}, \mathrm{Pc}, \mathrm{Pd}, \mathrm{Pe}$, and Pf. Every treatment must be observed about height of the plant every week in 3 weeks.

Result of the research shows that fertilizer A contains $1,119 \% \mathrm{~N}, 1,748 \%$ $P$, and $1,19 \%$, and fertilizer $B$ contains $1,035 \% \mathrm{~N}, 1,873 \% \mathrm{P}$, and $1,15 \% \mathrm{~K}$. Growth of the tomato plant after observed shows that add organic fertilizer from
} 
coffee and coconut dregs tell the big differences about growth of the plant. The shortest height is Po because of the treatment for tomato plant which doesn't add organic fertilizer. Variation of organic fertilizer from coffee and coconut dregs is the most effective with $\mathrm{Pb}$ treatment and add 150 gram of fertilizer with $1 \mathrm{~kg}$ of planting media.

Keywords :Quality, Organic fertilizer, Coffe Pulp and Coconut Pulp

\section{A. PENDAHULUAN}

\subsection{Latar Belakang}

Indonesia merupakan negara yang memiliki tanah yang sangat subur dan bisa dimanfaatkan untuk pertanian dan perkebunan, seperti padi, jagung, kopi, teh, kelapa dan lain sebagainya. Masyarakat sering kali membuang ampas kopinya ke saluran air dan belum banyak dimanfaatkan kembali. Terlebih jika ampas yang dibuang ke lingkungan tanpa dimanfaatkan dalam jumlah yang besar maka hanya akan menambah limbah cair.

Ampas kopi mengandung $2,28 \%$ nitrogen, fosfor $0,06 \%$ dan $0,6 \%$ kalium. pH ampas kopi sedikit asam yaitu berkisar 6,2 pada skala pH. Ampas kelapa banyak berasal dari industri santan dan industri minyak kelapa yang berupa daging kelapa parut. Ampas yang dihasilkan dari pengolahan kelapa ini memiliki nutrisi yang cukup tinggi. Analisis ampas kelapa kering (bebas lemak) mengandung 93\% karbohidrat yang terdiri atas $61 \%$ galaktomanan, $26 \%$ manosa dan $13 \%$ selulosa.

Sedangkan Banzon dan Velasco (1982), melaporkan bahwa tepung ampas kelapa mengandung lemak $12,2 \%$, protein $18,2 \%$, serat kasar 20\%, abu 4,9\% dan kadar air 6,2\%. Pemanfaatan ampas kopi dan ampas kelapa ini juga merupakan usaha untuk memanfaatkan bahan yang tidak terpakai lagi bagi konsumsi manusia. Ampas kelapa biasanya tidak diperjual-belikan, dapat diperoleh cukup banyak dari tempat-tempat penghasil makanan manusia yang menggunakan bahan dasar kelapa. Sedangkan ampas kopi banyak ditemukan pada tempat makan yang menyajikan menu kopi.

\subsection{Rumusan Masalah}

Berdasarkan latar belakang tersebut, maka terdapat beberapa perumusan masalah, antara lain :

1) Berapa kadar $N, P, K$ dan $C / N$ rasio pada pupuk organik dari ampas kopi dan ampas kelapa?

2) Bagaimana pengaruh variasi pemberian pupuk organik sebesar 100 gram, 150 gram dan 200 gram terhadap pertumbuhan tanaman tomat?

3) Berapakah dosis optimumpupuk organik terhadap pertumbuhan tanaman tomat?

\subsection{Batasan Masalah}

Dalam upaya mempermudah pemahaman dalam penelitian maka 
masalah yang dibatasi sebagai berikut :

1) Variasi dosis pupuk organik terhadap tanaman tomat adalah 100 gram, 150 gram dan 200 gram.

2) Variasi kadar ampas kelapa adalah 200 gram dan 300 gram

3) Parameter yang diamati adalah kandungan $\mathrm{N}, \mathrm{P}, \mathrm{K}$ dan $\mathrm{C} / \mathrm{N}$ rasio pada pupuk organik dan tinggi tanaman tomat.

\subsection{Tujuan Penelitian}

Sesuai permasalahan yang ada, maka tujuan dari penelitian ini adalah :

1) Mengetahui kadar $N, P$ dan $K$ pada pupuk organik dari ampas kopi dan ampas kelapa.

2) Mengetahui pengaruh variasi dosis pupuk organik sebesar 100 gram, 150 gram dan 200 gram terhadap pertumbuhan tanaman tomat.

Mengetahui dosis optimumpupuk organik terhadap pertumbuhan tanaman tomat.

\subsection{Manfaat Penelitian}

Penelitian ini diharapkan dapat memberi manfaat sebagai berikut:

1) Sebagai masukan bagi masyarakat khususnya petani tomat untuk memanfaatkan dan mempertimbangkan penggunaan pupuk organik serta informasi dalam memanfaatkan limbah ampas kopi dan ampas kelapa.
2) Sebagai sarana informasi bagi peneliti lain yang ingin melanjutkan penelitian ini

\section{TINJAUAN PUSTAKA}

\subsection{Tanaman Tomat}

Tomat

(Solanum lycopersicum) adalah tanaman yang sudah tidak asing lagi di masyarakat Indonesia. Tomat sering dijadikan sebagai lalapan, dicampurkan dalam masakan bahkan disajikan menjadi minuman yang menyegarkan yaitu jus. Tomat yang masak banyak digemari orang, karena rasanya segar, enak dan sedikit masam.

\subsection{Klasifikasi Tanaman Tomat (Solanum lycopersicum)}

Klasifikasi tomat adalah sebagai berikut :

$\begin{array}{ll}\text { Kingdom } & : \text { Plantae } \\ \text { Divisi } & :\end{array}$

Spermatophyta

Kelas

Dicotyledoneae

$\begin{array}{ll}\text { Ordo } & : \text { Solanales } \\ \text { Famili } & : \text { Solanaceae } \\ \text { Genus } & : \text { Solanum } \\ \text { Spesies } & : \text { Solanum }\end{array}$

lycopersicum Mill

2.2.1 Morfologi dan Anatomi Tanaman Tomat

Tanaman tomat merupakan tanaman herba annual atau biennial. Tanaman tomat mengalami pertumbuhan sekunder di awal, memiliki cabang yang relatif kuat, membentang hingga $1 \mathrm{~m}$ dari pusat 
batang. Stem (batang) tegak atau menjalar, trikoma uniseluler, trikoma berukuran $3 \mathrm{~mm}$ dan terletak di noduls serta rapat, trifoliate simpodial dan ruas batang berukuran $1-4 \mathrm{~cm}$.

Sebagian besar pembelahan sel dalam pericarp berlangsung selama 10-14 hari pertama setelah berbunga. Kulit buah (exocarp) terdiri dari lapisan epidermis luar ditambah 2-4 lapisan sel hopodermal berdinding tebal dengan kolenkim seperti bahan pengental. Dalam proses perkembangan awal buah, plasenta mulai memperluas ke lokula untuk menyerap biji dalam 10 hari pertama dan mengisi seluruh rongga lokula dalam beberapa hari berikutnya. Pada buah yang belum matang terbentuk plasenta dan setelah matang terbentuk lokula. Cairan intraseluler dapat terakumulasi dalam lokula dan protoplas tetap utuh (Jones, 2008).

\subsubsection{Siklus Hidup Tanaman Tomat}

Siklus hidup tanaman tomat yang di review dari Lippman et al (2008) adalah sebagai berikut :

Tanaman tomat adalah tanaman tahunan berumur pendek dengan masa hidup 5-6 bulan. Siklus hidup tanaman tomat meliputi tahap biji, vegetatif, reproduktif dan perkembangan buah. Perkecambahan biji pada tomat termasuk dalam kategori perkecambahan epigeal, dimana radikula muncul dan diikuti dengan memanjangnya hipokotil dan membawa serta kotiledon dan plamula ke atas permukaan tanah. Tahap biji meliputi dormansi dan germinasi. Germinasi biasanya terjadi pada kondisi optimal yang ditandai dengan munculnya radikula kira-kira 5-10 hari setelah penanaman biji.

Tahap perkembangan buah meliputi tahap fruit set, developing fruit, green fruit, breaker stage, turning stage, pink stage, light red stage dan ripe. Fruit stage ditandai oleh petal dan anther mengalami senesnce dan akhirnya gugur. Selanjutnya, buah seukuran kacang muncul. Dari titik ini sampai buah bisa dipanen dibutuhkan 40-50 hari. Developing fruit ditandai oleh buah yang berwarna hijau dan sangat keras. Pembelahan sel yang intensif terjadi tetapi pertumbuhan buah secara keseluruhan berlangsung lambat, memerlukan waktu 2-3 minggu (Lippman et al,2008).

\subsubsection{Manfaat dan Kandungan Tomat}

Kandungan yang terdapat dalam buah tomat meliputi alkaloid solanin $(0,007 \%)$, saponin, asam folat, asam malat, asam sitrat, biflavonoid, protein, lemak, gula (fruktosa, glukosa), adenine, trigonelin, kolin, tomatin, mineral (Ca, Mg, P, K, Na, Fe, sulfur, klorin), vitamin (B1, B2, B6, C, E, niasin), histamin dan likopen (Dalimartha, 2007). 


\subsection{Klasifikasi Tanaman Kelapa (Cocus nucifera $\mathbf{L}$ )}

Menurut Suhardiman

"dalam" Kailaku (2003) klasifikasi tanaman kelapa adalah :

Divisi :Spermatophyta (tumbuhan berbiji)

Kelas :Monocotyledionae

(biji

berkeping satu)

Ordo : Palmales

Famili : Palmae

Genus : Cocos

Spesies: Cocos nucifera $L$

\subsection{Limbah Ampas Kelapa}

Ampas industri pengolahan kelapa memiliki nilai gizi dan kandungan serat tinggi yang sangat baik bagi kesehatan. Akan tetapi selama ini ampas kelapa hanya diolah menjadi pakan ternak dengan harga yang sangat rendah (Yamin. 2008).

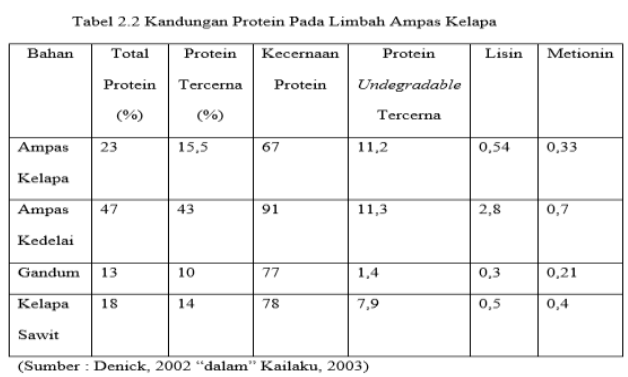

\subsection{Klasifikasi Tanaman Kopi}

Klasifikasi kopi menurut Cronquist (1981) adalah sebagai berikut :

$\begin{array}{ll}\text { Regnum } & \text { : Plantae } \\ \text { Divisio } & \text { : Magnoliophyta } \\ \text { Sub Divisio } & \text { : Spermatophyta } \\ \text { Class } & \text { : Magnoliopsida } \\ \text { Sub Class } & \text { : Asteridae } \\ \text { Order } & \text { : Rubiales } \\ \text { Family } & \text { : Rubiaceae } \\ \text { Genus } & \text { : Coffea } \\ \text { Species } & : \text { Coffea robusta }\end{array}$

2.6 Limbah Ampas Kopi
Limbah Ampas kopi merupakan pupuk organik yang ekonomis dan ramah lingkungan. Ampas kopi mengandung 2,28\% nitrogen., fosfor $0,06 \%$ dan $0,6 \%$ kalium. pH ampas kopi sedikit asam, berkisar 6,2 pada skala $\mathrm{pH}$. Selain itu, ampas kopi mengandung magnesium, sulfur dan kalsium yang berguna bagi pertumbuhan tanaman (Losito, 2011).

\subsection{Effective Microorganism 4 (EM 4) \\ Effective Microorganism 4}

(EM 4) merupakan mikroorganisme (bakteri) pengurai yang dapat membantu dalam pembusukan sampah organik (Maman Suparman, 1994:3). Effective Microorganism 4 (EM 4)berisi sekitar 80 genus mikroorganisme fermentasi, diantaranya bakteri fotositetik, Lactobacillus sp, Streptomyces sp, Actinomycetes $s p$ dan ragi (Redaksi Agromedia, 2007:33). EM4 digunakan untuk pengomposan modern. EM4 diaplikasikan sebagai inokulan untuk meningkatkan keragaman dan populasi mikroorganisme di dalam tanah dan tanaman yang selanjutnya dapat meningkatnya kesehatan, pertumbuhan, kualitas dan kuantitas produksi tanaman (Maman Suparman, 1994:3). Kompos yang dihasilkan dengan cara ini ramah lingkungan berbeda dengan kompos anorganik yang berasal dari zat-zat kimia. Kompos ini mengandung zatzat yang tidak dimiliki oleh pupuk anorganik yang baik bagi tanaman.

\subsection{1 \\ Sifat-sifatEffective Microorganism 4 (EM 4)}


Effective Microorganism 4 (EM 4)adalah suatu larutan kultur (biakan) dari mikroorganisme yang hidup secara alami di tanah yang subur serta bermanfaat untuk peningkatan produksi (Maman, 1994:4).

\subsubsection{PemanfaatanEffective \\ Microorganism 4 (EM 4)}

Menurut Maman Suparman (1994:3), Effective Microorganism 4 (EM 4) dapat ditambahkan dalam pengomposan sampah organik karena ia dapat mempercepat proses pengomposan. Effective Microorganism $4 \quad(E M \quad 4)$ diaplikasikan sebagai inokulan untuk meningkatkan keragaman dan populasi mikroorganisme di dalam tanah dan tanaman (Maman Suparman, 1994:3). Selain itu, Effective Microorganism 4 (EM 4) dapat digunakan untuk mempercepat dekomposisi sampah organik juga dapat meningkatkan pertumbuhan serta dapat meningkatkan kualitas dan kuantitas produksi tanaman (Maman Suparman, 1994:3).

\subsection{Pengomposan}

Pengomposan merupakan proses dekomposisi terkendali secara biologis terhadap limbah padat organik dalam kondisi aerobik (terdapat oksigen) atau anaerobik (tanpa oksigen). Kondisi yang terkendali tersebut meliputi rasio karbon dan nitrogen ( $\mathrm{C} / \mathrm{N}$ ratio), kelembaban, $\mathrm{pH}$, dan kebutuhan oksigen (Riyo Samekto, 2006:24). Konsep dasar dari pengomposan adalah merangsang perkembangan dan aktivitas mikroorganisme pengurai untuk mengubah bahan organik menjadi unsur-unsur yang siap diserap oleh tanaman (Redaksi AgroMedia, 2007:31). Menurut Redaksi AgroMedia (2007:31), bahwa konsep ini sama dengan proses terbentuknya humus oleh alam dengan bantuan mikroorganisme baik secara aerob maupun anaerob.

\subsection{Pupuk Organik}

Ketersediaan hara dalam tanah sangat dipengaruhi oleh mekanisme mineral liat yang mempunyai hubungan erat terhadap sifat fisika dan kimia tanah. Setiap macam tanah memberikan ketersediaan hara yang berbeda. Penggunaan pupuk yang mencakup jenis/macam, dosis, waktu dan cara pemupukan masih kurang rasional dan kurang tepat sehingga efisiensi penggunaan pupuk masih kurang bahkan dapat mencemari lingkungan.

Pupuk Organik merupakan salah satu usaha yang dilakukan untuk memperbaiki kesuburan tanah adalah dengan melakukan pemupukan menggunakan pupuk organik. Kandungan unsur hara dalam pupuk kandang tidak terlalu tinggi, tetapi jenis pupuk ini mempunyai lain yaitu dapat memperbaiki sifat - sifat fisik tanah seperti permeabilitas tanah, porositas tanah, struktur tanah, daya menahan air dan kation - kation tanah.

\subsubsection{Kelebihan dan Kelemahan Penggunaan Pupuk Organik}

Kelebihan penggunaan pupuk organik pada tanaman yaitu:

1) Keseimbangan tanah dapat terjaga karena tidak menggunakan pupuk dan pestisida kimia, tetapi menggunakan pupuk organik 
seperti pupuk kandang, pupuk hijau dan sisa tanaman.

2) Dengan menghindari pemakaian pestisida secara berlebihan akan dapat mengurangi resiko keracunan zat tersebut sehingga masyarakat dapat mengkonsumsi makanan yang sehat.

3) Meningkatkan kesadaran masyarakat akan menjamin kesehatan produk pertanian yang akan menaikkan jumlah yang ingin dibayar terhadap komoditi tersebut sehingga dapat meningkatkan kesejahteraan petani.

4) Menghasilkan bahan pangan yang cukup aman, bergizi, sehingga dapat meningkatkan kesehatan masyarakat sekaligus daya saing produksi agribisnis.

5) Meningkatkan dan menjaga produktifitas lahan pertanian dalam jangka waktu panjang serta melestarikan sumber daya alam (SDA) dan lingkungan.

Sedangkan kelemahan dari penggunaan pupuk organik sebagai berikut:

1) Membutuhkan pengelolaan lahan yang cukup rumit.

2) Membutuhkan waktu yang cukup lama untuk mendapatkan hasil yang lebih maksimal, karena harus melalui tahap konversi terlebih dahulu.

3) Apabila diterapkan pada skala usaha yang besar akan memakan biaya yang tinggi terutama pada biaya tenaga kerja pada saat ekosistem lingkungan belum terbangun.

\subsubsection{Pengaruh Pemupukan Pada Kesuburan Tanah}

Penggunaan pupuk secara setimbang akan meningkatkan produksi tanaman. Peningkatan produksi juga meningkatkan jumlah sisa - sisa tanaman (daun, batang, akar) yang tertinggal atau yang dapat dikembalikan ke dalam tanah. Kesetimbangan unsur hara tentang pengembalian $80 \%$ sisa - sisa tanaman dapat memperkaya cadangan unsur hara, sehingga mengurangi kebutuhan hara yang harus ditambahkan. Perlakuan ini jika dilakukan secara terus menerus akan mengurangi kebutuhan hara sehingga akan dicapai kondisi hara yang cukup untuk pertumbuhan dan produksi tanaman tinggi tanpa ada masukan pupuk dari luar. Pengembalian sisa - sisa tanaman ini akan memperbaiki sifat - sifat kimia dan fisika tanah, meningkatkan kemampuan menyimpan air, meningkatkan kemudahan pengolahan dan kesuburan tanah.

\subsection{Kerangka Berpikir}

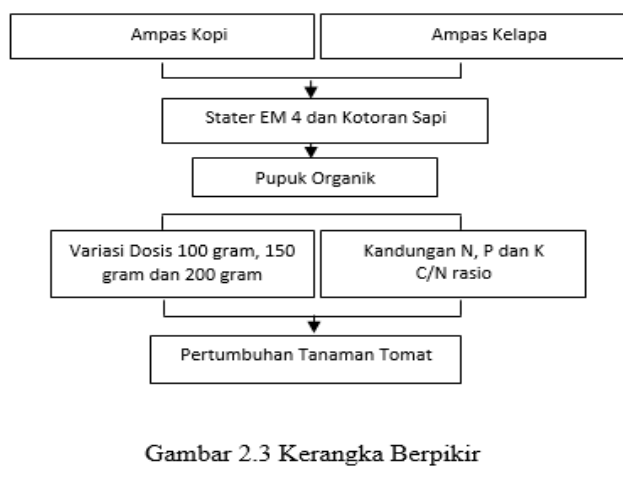

\subsection{Hipotesis}

Berdasarkan perumusan masalah, tujuan dan kerangka berpikir, maka akan diajukan hipotesis sebagai berikut: 
1) Kandungan $\mathrm{N}, \mathrm{P}$ dan $\mathrm{K}$ dan $\mathrm{C} / \mathrm{N}$ rasio pada pupuk organik dari ampas kopi dan ampas kelapa memenuhi syarat teknis minimal pupuk organik padat.

2) Ada pengaruh pemberian pupuk organik yang sangat nyata terhadap pertumbuhan tanaman tomat.

3) Dosis optimum pupuk organik dari ampas kopi dan ampas kelapa adalah 200 gram pada kadar ampas kelapa sebanyak 300 gram.

\section{METODOLOGI PENELITIAN}

\subsection{Lokasi Penelitian}

Lokasi penelitian pupuk organik dan Pengamatan Tanaman Tomat dilaksanakan di Jalan Maguwo no.140 Desa Wonocatur Kecamatan Banguntapan Kabupaten Bantul Daerah Istimewa Yogyakarta sedangkan penelitian kandungan $\mathrm{N}$, $\mathrm{P}, \mathrm{K}$ dan $\mathrm{C} / \mathrm{N}$ rasio pada pupuk akan dilaksanakan di Laboratorium Sentral INSTIPER yang beralamat di Jalan Persada IV No.224, Maguwoharjo, Kecamatan Depok, Kabupaten Sleman, Yogyakarta.

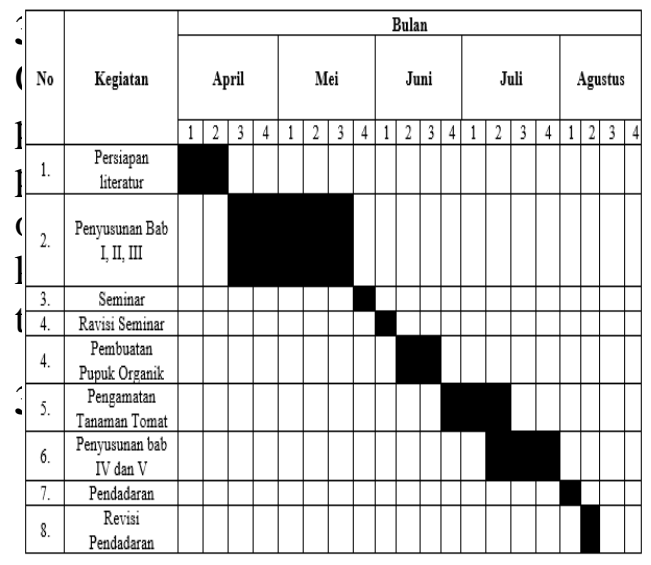

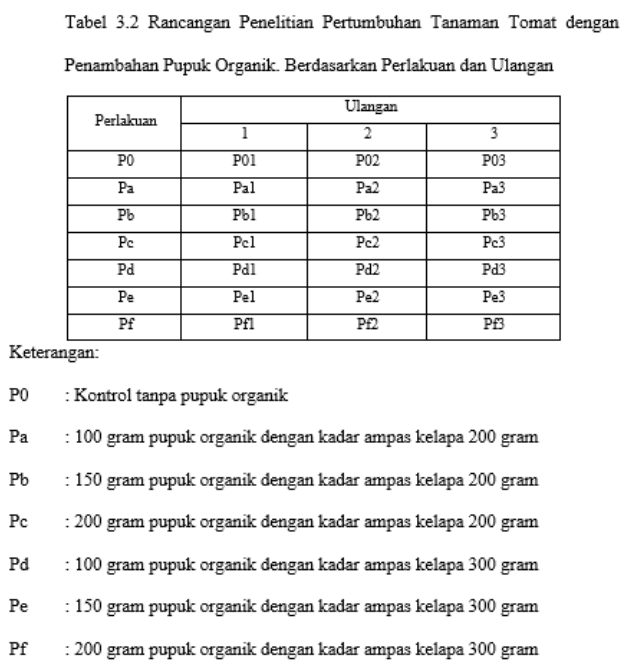

\subsection{Variabel Penelitian}

Variabel yang digunakan dalam penelitian ini adalah variabel bebas dan variabel terikat:

1) Variabel Bebas

a. Komposisi ampas kelapa sebesar 200 gram dan 300 gram pada pembuatan pupuk

b. Dosis pupuk pada tanaman sebesar 100 gram : 150 gram : 200 gram per 1000 gram media tanam.

2) Variabel Terikat
a. Kandungan $\mathrm{N}, \mathrm{P}, \mathrm{K}$ dan $\mathrm{C} / \mathrm{N}$ rasio pada pupuk
b. Tinggi tanaman tomat.

\subsection{Jenis Penelitian}

Jenis penelitian yang digunakan adalah

dengan rancangan percobaan Rancangan Acak Lengkap (RAL) terdiri dari 7 perlakuan dan 3 ulangan.

\subsection{Alat dan Bahan}

Alat yang digunakan dalam penelitian ini yaitu :

- 21 buah polybag

- 1 buah sendok 
- 1 buah penyemprot tanaman

- 1 buah mistar pengukur

- 1 buah pisau

- 1 buah camera.

- 4 buah terpal ukuran $1 \mathrm{~m}$ x 1 $\mathrm{m}$

- 1 buah termometer

- 1 buah soilmeter

Bahan yang digunakan dalam penelitian ini yaitu :

- 500 gram ampas kelapa yang dikeringkan

- 400 gram ampas kopi yang dikeringkan

- 600 gram abu sekam/sekam padi

- 600 gram kapur pertanian (dolomit)

- $2 \mathrm{~kg}$ kotoran sapi kering

- $60 \mathrm{ml} \mathrm{EM} 4$

- $500 \mathrm{ml}$ air

- 21 bibit tanaman tomat (umur 2 minggu, dibeli dari penjual tanaman).

\subsection{Tahapan Penelitian}

Tahapan penelitian meliputi tahapan pembuatan pupuk organik sampai dengan tahap pengamatan pertumbuhan tanaman.

- Tahapan Pembuatan Pupuk Organik Dengan Kadar Ampas Kelapa 200 gram

1) Komposisi pupuk organik adalah $1 \mathrm{~kg}$ kotoran sapi kering : 300 gram sekam padi : 300 gram kapur : 200 gram ampas kopi : 200 gram ampas kelapa : $30 \mathrm{ml} \mathrm{em4.}$

2) Menyiapkan tempat yang ternaungi dan jika hujan tempat tersebut tidak tergenang air dan alasnya dilapisi terpal untuk wadah bahan pupuk organik.
3) Melakukan proses pencampuran bahan yaitu 1 $\mathrm{kg}$ kotoran sapi diratakan pada terpal seluas $1 \mathrm{~m} \mathrm{x} 1 \mathrm{~m}$.

4) Meratakan 200 gram ampas kopi dan 200 gram ampas kelapa di atas tumpukan kotoran sapi.

5) Meratakan 300 gram sekam padi dan 300 gram kapur di atas tumpukan kotoran sapi, ampas kopi dan ampas kelapa.

6) Menyiapkan $30 \mathrm{ml} \mathrm{EM} 4$ yang dilarutkan pada $500 \mathrm{ml}$ air dan menyiramkan larutan EM4 ke tumpukan bahan pupuk organik dengan merata.

7) Kandungan air yang dinginkan diukur dengan cara meremas bahan dengan tangan. Ditandai dengan air tidak menetes atau bahan mekar bila genggaman tangan dibuka.

8) Lakukan pengadukan pada timbunan bahan pupuk organik hingga merata.

9) Timbunan ditutup dengan terpal.

10) Lakukan pengecekan suhu dan $\mathrm{pH}$ pada bahan pupuk organik setiap hari, bila suhu $30^{\circ}-60^{\circ} \mathrm{C}$ dan $\mathrm{pH} 5,5-9$ maka proses dikatakan baik.

11) Pengadukan bahan pupuk organik bisa dilakukan setiap hari atau ketika suhu bahan lebih dari $60^{\circ}$.

12) Perkirakan 3 minggu kompos sudah bisa dibongkar dan dianginkan supaya menghilangkan bau amoniak dan sudah dapat digunakan. 
13) Melakukan uji kandungan NPK pada pupuk organik.

- Tahapan Pembuatan Pupuk Organik Dengan Kadar Ampas Kelapa 300 gram

1) Komposisi pupuk organik adalah $1 \mathrm{~kg}$ kotoran sapi kering : 300 gram sekam padi : 300 gram kapur : 200 gram ampas kopi : 300 gram ampas kelapa : $30 \mathrm{ml} \mathrm{em} 4$.

2) Melakukan proses yang sama dengan pembuatan pupuk organik dengan kadar ampas kelapa 200 gram.

- Tahap Penyiapan Tanaman dan Pengamatan

1) Menyiapkan tanaman tomat umur 2 minggu.

2) Memasukkan sekam padi ke dalam polibag.

3) Tanaman tomat dimasukkan ke dalam polibag ukuran 1 $\mathrm{kg}$, kemudian diberi label.

4) Setelah diisi abu sekam, polybag dipindahkan atau disimpan pada tempat yang aman agar tidak rusak.

5) Proses pengamatan pertumbuhan tanaman tomat dilakukan dilahan terbuka untuk memberikan intensitas cahaya yang cukup bagi tanaman.

6) Tanaman tomat disiram setiap hari yakni pada sore hari.

7) Melakukan pengumpulan data dengan mengukur tinggi tanaman selama 1 minggu sekali menggunakan alat ukur penggaris $30 \mathrm{~cm}$, pengukuran dilakukan sebanyak 3 kali.
8) Hasil pengamatan dimasukkan pada tabel.

\subsection{Analisis Data}

Analisis data digunakan untuk membuktikan kebenaran hipotesis yang diajukan. Analisis dilakukan secara kualitatif yaitu dengan analisis varian (Anava) satu jalur. Langkah pertama yaitu melakukan uji homogenitas pada data yang tersedia. Setelah data teruji homogen dilakukan uji Anava satu jalur untuk mengetahui rata- rata tinggi tanaman berbeda atau sama. Jika dari uji Anava didapat tinggi rata- rata berbeda nyata maka dilakukan uji lanjut LSD (Least Significant Difference) untuk mengetahui ada tidaknya pengaruh pemberian perlakuan pada tinggi tanaman tomat (Solanum lycopersicum).

\section{HASIL DAN PEMBAHASAN}

\subsection{Hasil Penelitian}

Penelitian "Pemanfaatan Ampas Kopi dan Ampas Kelapa Sebagai Pupuk Organik Pada Tanaman Tomat dilakukan selama 5 minggu, dimulai pada tanggal 15 Juni 2017 sampai dengan 24 Juli 2017 sekaligus dengan pengujian kadar C Organik, N, P dan K pada pupuk organik. Parameter yang diamati meliputi C Organik, N, P dan $\mathrm{K}$. Hasil laboratorium menunjukkan kadar yang mememuhi beberapa parameter sesuai dengan Peraturan Menteri Pertanian No.70. Pengamatan tinggi tanaman tomat dilaksanakan selama 3 minggu, dimulai dari tanggal 3 Juli 2017 sampai dengan 24 Juli 2017. Hasil penelitian mengenai pertumbuhan 
tanaman tomat menujukkan pengaruh yang berbeda nyata pada perbedaan pemberian variasi pupuk organik.

\subsection{Kandungan Pupuk Organik}

\subsection{Hasil Pengamatan Pertumbuhan Tanaman Tomat}

\begin{tabular}{|c|c|c|c|}
\hline $\begin{array}{l}\text { Pupuk } \\
\text { Organik }\end{array}$ & Parameter & Jumlah & $\begin{array}{c}\text { Syarat Teknis Permentan } \\
\text { No. } 70 \text { Tahun } 2011\end{array}$ \\
\hline \multirow[t]{4}{*}{$\mathrm{A}$} & $\mathrm{C} / \mathrm{N}$ & 25,612 & $15-25$ \\
\hline & $\mathrm{N}$ & 1,104 & $\operatorname{Min} 4 \%$ \\
\hline & $P$ & 1,741 & $\operatorname{Min} 4 \%$ \\
\hline & $\mathrm{K}$ & 1,190 & $\operatorname{Min} 4 \%$ \\
\hline \multirow[t]{4}{*}{$B$} & $\mathrm{C} / \mathrm{N}$ & 25,513 & $15-25$ \\
\hline & $\mathrm{N}$ & 1,050 & $\operatorname{Min} 4 \%$ \\
\hline & $P$ & 1,850 & $\operatorname{Min} 4 \%$ \\
\hline & $\mathrm{K}$ & 1,155 & $\operatorname{Min} 4 \%$ \\
\hline
\end{tabular}

Tabel 4.3 menunjukkan bahwa kadar $\mathrm{N}$, $\mathrm{P}$ dan $\mathrm{K}$ pupuk organik dari ampas kopi dan ampas kelapa dapat menghasilkan kadar yang belum memenuhi syarat teknis pupuk organik.

Tabel 4.4 Hasil Pengamatan Tinggi Tanaman Minggu Ke-1

\begin{tabular}{|c|c|c|c|c|c|}
\hline \multirow{3}{*}{ Perlakuan } & \multirow{3}{*}{ N } & \multirow{2}{*}{\multicolumn{3}{|c|}{$\begin{array}{c}\text { Minggu 1 } \\
\text { Pertumbuhan Tinggi Tiap } \\
\text { Perlakuan }(\mathrm{cm})\end{array}$}} & \multirow{3}{*}{$\begin{array}{l}\text { Rata-Rata } \\
\text { (cm) }\end{array}$} \\
\hline & & & & & \\
\hline & & 1 & 2 & 3 & \\
\hline Po & 3 & 8.4 & 8.4 & 8.1 & 8.3 \\
\hline $\mathrm{Pa}$ & 3 & 9.9 & 9.3 & 9.4 & 9.5 \\
\hline $\mathrm{Pb}$ & 3 & 9.3 & 9.8 & 9.5 & 9.5 \\
\hline $\mathrm{Pc}$ & 3 & 10.7 & 10.5 & 10.4 & 10.5 \\
\hline $\mathrm{Pd}$ & 3 & 9.1 & 9.3 & 9.1 & 9.2 \\
\hline $\mathrm{Pe}$ & 3 & 8.8 & 8.9 & 9.1 & 8.9 \\
\hline Pf & 3 & 9.2 & 9.3 & 9.1 & 9.2 \\
\hline
\end{tabular}

Tabel 4.4 menunjukkan perbedaan yang berbeda namun belum signifikan antara Po dan variasi pemberian pupuk. Perlakuan Pc merupakan variasi dosis yang paling besar sigfinikan perbedaan tingginya. Adapun Po merupakan pertumbuhan tinggi tanaman yang paling kecil.

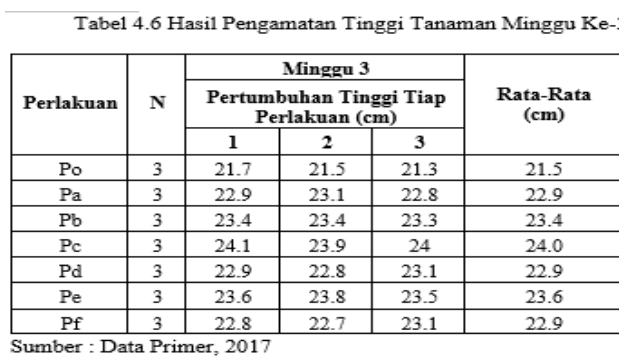

Tabel 4.5 menunjukkan perbedaan tinggi hampir $180 \%$ dari pebedaan tinggi tanaman minggu pertama. Untuk selisih pertumbuhan tinggi antar variasi dosis pupuk hasilnya masih kecil. Namun Pc memiliki angka paling tinggi selisihnya dan Po paling rendah. Selisih rata - rata pertumbuhan tinggi antar $\mathrm{Pc}$ dan Po adalah $3,6 \mathrm{~cm}$.

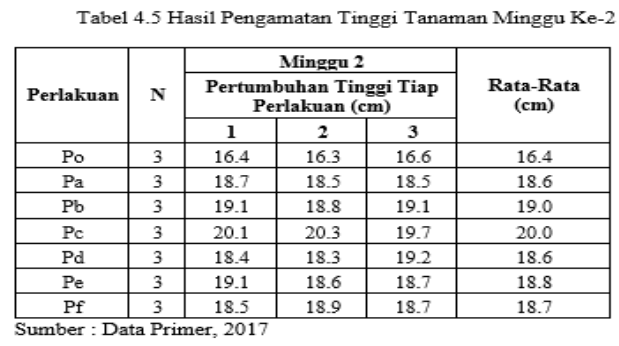

Tabel 4.6 menunjukkan bahwa perlakuan Pc memang memiliki selisih tinggi tanaman paling tinggi diantara variasi yang lain yaitu rata rata 1-3 cm. Sementara Po dengan selisih pertumbuhan tinggi paling rendah dan berbeda $3,5 \mathrm{~cm}$ dari perlakuan Pc.

\subsection{Hasil Analisa Statistik}

Analisa statistik dilakukan terhadap perbedaan pertumbuhan tinggi tanaman antar variasi pemberian pupuk setiap minggunya menggunakan software SPSS. Analisa yang dilakukan meliputi uji homogenitas, uji anova satu jalur dan uji LSD (Least Significant Difference). 


\subsubsection{Hasil Analisa Data Minggu Ke-1}

Tabel 4.7 Uji Homogenitas Data Minggu ke-1

Test of Homogeneity of Variances

Tinggi Tanaman

\begin{tabular}{|c|c|c|c|}
\hline Levene Statistic & df1 & $d f 2$ & Sig. \\
\hline 1.604 & 6 & 14 & .218 \\
\hline
\end{tabular}

Sumber : Data Primer, 2017

Dari hasil uji homogenitas diperoleh nilai probilitas 0,218. Dapat diketahui bahwa 0,218>0,05 maka H0 diterima, artinya ketujuh varians adalah sama. Setelah ketujuh varian terbukti sama maka dilakukan uji Anova satu jalur.

Tabel 4.8 Hasil Uii Anova 1 Jalur Data Minggu ke-1

ANOVA

Tinggi Tanaman
\begin{tabular}{|l|r|r|r|c|r|}
\hline & Sum of Squares & df & Mean Square & F & Sig. \\
\hline Between Groups & 8.372 & 6 & 1.395 & 36.628 & .000 \\
Within Groups & .533 & 14 & .038 & & \\
Total & 8.900 & 20 & & & \\
\hline
\end{tabular}

Sumber : Data Primer, 2017

Keterangan :

$$
\begin{array}{ll}
\text { F Hitung } & =36,629 \\
\text { F Tabel } & =2,85
\end{array}
$$

Pada Uji Anova digunakan titik presentase distribusi $\mathrm{F}$ yaitu 5 $\%$. Hasil uji Anova menunjukkan bahwa F Hitung > F Tabel, diperoleh keputusan $\mathrm{H} 0$ ditolak yaitu rata rata tinggi tanaman tidak sama atau berbeda nyata. Setelah diketahui bahwa ada perbedaan yang signifikan diadakan uji lanjut LSD.

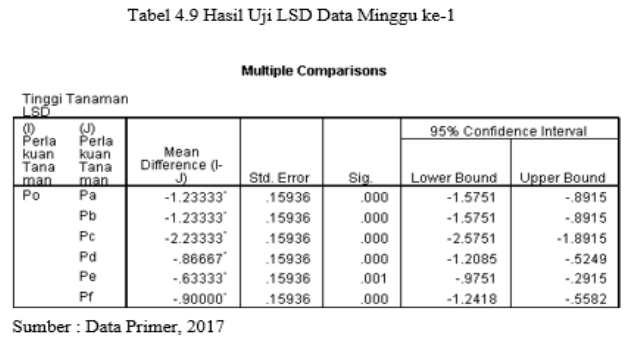

Dari hasil uji LSD diketahui bahwa perbedaan rata - rata tinggi tanaman perlakuan Po dengan $\mathrm{Pa}$ adalah 1,23 dengan nilai probabilitas 0,000 . Dapat diketahui bahwa $0,000<0,05$ maka dapat diambil keputusan bahwa pemberian pupuk organik pada perlakuan $\mathrm{Pa}$ berpengaruh terhadap pertumbuhan tanaman tomat. Perbedaan rata - rata tinggi tanaman pada perlakuan Po dengan $\mathrm{Pb}$ adalah 1,23 dengan nilai probabilitas 0,000. Maka dapat diambil keputusan bahwa pemberian pupuk organik pada perlakuan $\mathrm{Pb}$ berpengaruh terhadap pertumbuhan tanaman tomat. Perbedaan rata - rata tinggi tanaman pada perlakuan Po dengan Pc adalah 2,23 dengan nilai probabilitas 0,000 . Maka dapat diambil keputusan bahwa pemberian pupuk organik berpengaruh terhadap pertumbuhan tanaman tomat. Perbedaan rata - rata tinggi tanaman pada perlakuan Po dengan Pd adalah 0,86 dengan nilai probabilitas 0,000 .

Maka dapat diambil keputusan bahwa pemberian pupuk organik berpengaruh terhadap pertumbuhan tanaman tomat. Perbedaan rata - rata tinggi tanaman pada perlakuan Po dengan Pe adalah 0,63 dengan nilai probabilitas 0,001. Maka dapat diambil keputusan bahwa pemberian pupuk organik berpengaruh terhadap pertumbuhan tanaman tomat. Perbedaan rata - rata tinggi tanaman pada perlakuan Po dengan Pf adalah 0,90 dengan nilai probabilitas 0,000 . Maka dapat diambil keputusan bahwa pemberian pupuk organik berpengaruh terhadap pertumbuhan tanaman tomat. 


\subsubsection{Hasil Analisis Data Minggu Ke-2}

Tabel 4.10 Uji Homogenitas Data Minggu ke-2

Test of Homogeneity of Variances

Tinggi Tanaman

\begin{tabular}{|c|c|c|c|}
\hline Levene Statistic & df1 & $d f 2$ & Sig. \\
\hline 2.521 & 6 & 14 & .072 \\
\hline
\end{tabular}

Sumber : Data Primer, 2017

Dari hasil uji homogenitas diperoleh nilai probabilitas 0,072 . Dapat diketahui bahwa 0,072 >0,05 maka H0 diterima, artinya ketujuh varian adalah sama. Maka dilakukan uji Anova satu jalur.

Tabel 4.11 Uji Anova Data Minggu ke-2

ANOVA

Tinggi Tanaman
\begin{tabular}{|l|r|r|r|c|r|}
\hline & Sum of Squares & df & Mean Saure & F & Siq. \\
\hline Between Groups & 20.883 & 6 & 3.480 & 47.481 & .000 \\
Within Groups & 1.027 & 14 & .073 & & \\
Total & 21.910 & 20 & & & \\
\hline
\end{tabular}

Sumber : Data Primer, 2017

Keterangan :

\begin{tabular}{ll} 
F Hitung & $=47,461$ \\
\hline F Tabel & $=2,85$
\end{tabular}

Hasil uji

Anova

menunjukkan F Hitung > F Tabel, diperoleh keputusan $\mathrm{HO}$ ditolah yaitu rata - rata tinggi tanaman tidak sama atau berbeda nyata.

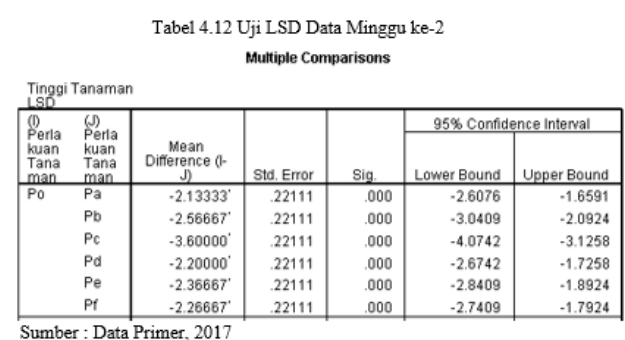

Dari hasil uji LSD diketahui bahwa perbedaan rata - rata tinggi tanaman perlakuan $\mathrm{Po}$ dengan $\mathrm{Pa}$ adalah 2,13 dengan nilai probabilitas 0,000 . Dapat diketahui bahwa 0,000 $<0,05$ maka dapat diambil keputusan bahwa pemberian pupuk organik pada perlakuan $\mathrm{Pa}$ berpengaruh terhadap pertumbuhan tanaman tomat. Perbedaan rata - rata tinggi tanaman pada perlakuan Po dengan $\mathrm{Pb}$ adalah 2,56 dengan nilai probabilitas 0,000. Maka dapat diambil keputusan bahwa pemberian pupuk organik pada perlakuan $\mathrm{Pb}$ berpengaruh terhadap pertumbuhan tanaman tomat. Perbedaan rata - rata tinggi tanaman pada perlakuan Po dengan Pc adalah 3,36 dengan nilai probabilitas 0,000. Maka dapat diambil keputusan bahwa pemberian pupuk organik berpengaruh terhadap pertumbuhan tanaman tomat. Perbedaan rata - rata tinggi tanaman pada perlakuan Po dengan Pd adalah 2,20 dengan nilai probabilitas 0,000 .

Maka dapat diambil keputusan bahwa pemberian pupuk organik berpengaruh terhadap pertumbuhan tanaman tomat. Perbedaan rata - rata tinggi tanaman pada perlakuan Po dengan Pe adalah 2,36 dengan nilai probabilitas 0,000 . Maka dapat diambil keputusan bahwa pemberian pupuk organik berpengaruh terhadap pertumbuhan tanaman tomat. Perbedaan rata - rata tinggi tanaman pada perlakuan Po dengan Pf adalah 2,26 dengan nilai probabilitas 0,000 . Maka dapat diambil keputusan bahwa pemberian pupuk organik berpengaruh terhadap pertumbuhan tanaman tomat. 


\subsubsection{Hasil Analisa Data Minggu Ke-3}

Tabel 4.13 Uji Homogenitas Data Minggu ke-3

Test of Homogeneity of Variances

\begin{tabular}{|c|c|c|c|}
\hline Levene Statistic & df1 & df2 & Sig. \\
\hline .782 & 6 & 14 & .598 \\
\hline
\end{tabular}

Sumber : Data Primer, 2017

Dari hasil uji homogenitas diperoleh nilai probabilitas 0,598. Dapat diketahui bahwa 0,598 >0,05 maka H0 diterima, artinya ketujuh varian adalah sama. Selanjutnya dilakukan uji Anova satu jalur.

Tabel 4.14 Uji Anova 1 Jalur Data Minggu ke-3

ANOVA

Tinggi Tanaman
\begin{tabular}{|l|r|r|r|l|l|}
\hline & Sum of Squares & df & Mean Square & F & Sig. \\
\hline Between Groups & 11.413 & 6 & 1.902 & 79.893 & .000 \\
Within Groups & .333 & 14 & .024 & & \\
Total & 11.747 & 20 & & & \\
\hline
\end{tabular}

Sumber : Data Primer, 2017

Keterangan :

F Hitung $=79,893$

$\mathrm{F}$ Tabel $=2,85$

Hasil uji Anova menunjukkan bahwa F Hitung > Tabel, diperoleh keputusan H0 ditolak yaitu rata - rata tinggi tanaman berbeda nyata. Maka dilanjutkan uji LSD.

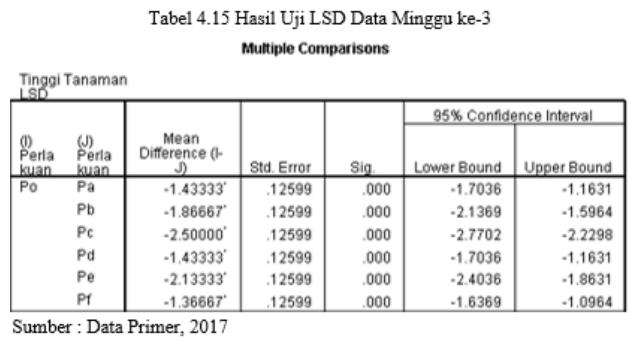

Dari hasil uji LSD diketahui bahwa perbedaan rata - rata tinggi tanaman perlakuan Po dengan $\mathrm{Pa}$ adalah 1,43 dengan nilai probabilitas 0,000 . Dapat diketahui bahwa 0,000 $<0,05$ maka dapat diambil keputusan bahwa pemberian pupuk organik pada perlakuan $\mathrm{Pa}$ berpengaruh terhadap pertumbuhan tanaman tomat. Perbedaan rata - rata tinggi tanaman pada perlakuan Po dengan $\mathrm{Pb}$ adalah 1,86 dengan nilai probabilitas 0,000 . Maka dapat diambil keputusan bahwa pemberian pupuk organik pada perlakuan $\mathrm{Pb}$ berpengaruh terhadap pertumbuhan tanaman tomat. Perbedaan rata - rata tinggi tanaman pada perlakuan Po dengan Pc adalah 2,25 dengan nilai probabilitas 0,000 .

Maka dapat diambil keputusan bahwa pemberian pupuk organik berpengaruh terhadap pertumbuhan tanaman tomat. Perbedaan rata - rata tinggi tanaman pada perlakuan Po dengan Pd adalah 1,43 dengan nilai probabilitas 0,000 . Maka dapat diambil keputusan bahwa pemberian pupuk organik berpengaruh terhadap pertumbuhan tanaman tomat. Perbedaan rata - rata tinggi tanaman pada perlakuan Po dengan Pe adalah 2,13 dengan nilai probabilitas 0,000 . Maka dapat diambil keputusan bahwa pemberian pupuk organik berpengaruh terhadap pertumbuhan tanaman tomat. Perbedaan rata - rata tinggi tanaman pada perlakuan Po dengan Pf adalah 1,36 dengan nilai probabilitas 0,000 . Maka dapat diambil keputusan bahwa pemberian pupuk organik berpengaruh terhadap pertumbuhan tanaman tomat. 


\subsection{Efektifitas Varian Pupuk Organik}

Untuk menentukan variasi pupuk organik yang paling efektif dengan menggunakan uji antar treatment.

$$
\text { Db LSD }=21-3=18
$$

Pada $\mathrm{db}$ 18, Tabel $\mathrm{T} \quad(5 \%)$ menunjukkan angka 2,101. Maka angka tersebut akan digunakan untuk membandingkan dengan nilai rata rata beda tinggi antar perlakuan. Hasil analisa dapat dilihat pada tabel LSD berikut ini :

|Tabel 4.17 Uji Antar Treatment (LSD)

\begin{tabular}{|c|c|c|c|c|}
\hline \multicolumn{2}{|c|}{$\begin{array}{c}\text { Daftar } \\
\text { Perlakuan }\end{array}$} & \multirow{2}{*}{$\begin{array}{c}\begin{array}{c}\text { Beda Mid } \\
\text { (Rata-rata) }\end{array} \\
1.43 \\
\end{array}$} & \multirow{2}{*}{$\begin{array}{l}\begin{array}{l}\text { Tabel } \\
\text { LSD }\end{array} \\
2.101\end{array}$} & \multirow{2}{*}{$\begin{array}{c}\text { Kesimpulan } \\
\text { NS } \\
\end{array}$} \\
\hline Po & $\mathrm{Pa}$ & & & \\
\hline & $\mathrm{Pb}$ & 1.87 & 2.101 & NS \\
\hline & $\mathrm{Pc}_{\mathrm{c}}$ & 2.50 & 2.101 & $\mathrm{~s}$ \\
\hline & $\mathrm{Pd}$ & 1.43 & 2.101 & NS \\
\hline & $\mathrm{Pe}$ & 2.13 & 2.101 & $\mathrm{~s}$ \\
\hline & Pf & 1.37 & 2.101 & NS \\
\hline \multirow[t]{5}{*}{$\mathrm{Pa}$} & $\mathrm{Pb}$ & 0.43 & 2.101 & NS \\
\hline & $\mathrm{Pc}_{\mathrm{c}}$ & 1.07 & 2.101 & NS \\
\hline & $\mathrm{Pd}$ & 0.00 & 2.101 & NS \\
\hline & $\mathrm{Pe}$ & 0.70 & 2.101 & NS \\
\hline & Pf & 0.07 & 2.101 & NS \\
\hline \multirow[t]{4}{*}{$\mathrm{Pb}$} & $\mathrm{Pc}$ & 0.63 & 2.101 & NS \\
\hline & $\mathrm{Pd}$ & 0.43 & 2.101 & NS \\
\hline & $\mathrm{Pe}$ & 0.27 & 2.101 & NS \\
\hline & Pf & 0.50 & 2.101 & NS \\
\hline \multirow[t]{3}{*}{$\mathrm{Pc}_{\mathrm{c}}$} & $\mathrm{Pd}$ & 1.07 & 2.101 & NS \\
\hline & $\mathrm{Pe}$ & 0.37 & 2.101 & NS \\
\hline & Pf & 1.13 & 2.101 & NS \\
\hline \multirow[t]{2}{*}{$\mathrm{Pd}$} & $\mathrm{Pe}$ & 0.70 & 2.101 & NS \\
\hline & Pf & 0.07 & 2.101 & NS \\
\hline $\mathrm{Pe}$ & Pf & 0.77 & 2.101 & NS \\
\hline
\end{tabular}

Dari tabel 4.17 menunjukkan nilai yang cukup kecil rata - rata selisih pertumbuhan tinggi tanaman antar perlakuan. Hanya Po x Pc dan Po x Pe yang memiliki perbedaan yang signifikan. Dari tabel diatas dapat diambil kesimpulan bahwa $\mathrm{Pb}$ merupakan varian paling efektif untuk pertumbuhan tanaman tomat.

\subsection{Pembahasan}

\subsubsection{Kandungan Pupuk Organik}

Kandungan C Organik, N, P dan $\mathrm{K}$ pada pupuk organik secara angka belum memenuhi seluruh syarat mutu pupuk organik padat yang tercantum dalam PERMENTAN NO.70. Namun itu lebih kecil dari kandungan pada pupuk organik pada umumnya, hal ini kemungkinan dikarenakan volume bahan yang jika dijumlah hanya sekitar $2 \mathrm{~kg}$. Kandungan N, P dan K pada kisaran $1 \%$ saja. Pada umumnya pembuatan pupuk dilakukan dengan volume minimal $100 \mathrm{~kg}$ bahan baku. Hal ini juga bisa mempengaruhi proses pembusukan pada pupuk yang kurang baik. Dilihat dari tingkat suhu maksimal hanya $40^{\circ} \mathrm{C}$, padahal proses pembusukan bisa mencapai suhu $60^{\circ}$ C. Namun suhu bisa cenderung stabil karena kegiatan pengadukan bahan pupuk dilakukan setiap hari sehingga proses aerasi berlangsung setiap hari yang membuat suhu pupuk tidak terlalu tinggi.

\subsubsection{Pertumbuhan Tinggi Tanaman Tomat}

Dari hasil penelitian yang dilakukan pemberian media dengan penambahan pupuk organik dari ampas kopi dan ampas kelapa berpengaruh sangat nyata pada tinggi tanaman. Adanya pengaruh tersebut karena adanya penambahan nutrisi pada media tumbuh tanaman tomat yang dapat meningkatan hasil yang diperoleh. Dalam hasil pengamatan tinggi tanaman tomat setiap minggu Po cenderung mengalami pertumbuhan yang paling lambat. Namun jika dilihat dari jumlah 
tingginya dari minggu pertama hingga minggu ketiga menunjukkan jika selisih tinggi antara Po dengan varian lain tidak terlalu signifikan kecuali dengan perlakuan Pc. Hal ini mengindikasikan bahwa media tanaman tomat yang digunakan telah terdapat kompos yang juga merupakan nutrisi bagi tanaman.

Perlakuan Pc menghasilkan perbedaan tinggi yang sangat signifikan dibanding dengan perlakuan yang lain. Dengan komposisi ampas kopi 200 gram dan ampas kelapa 200 gram. Dalam komposisi sebenarnya tidak berbeda jauh dengan varian pupuk yang lain, namun faktor cahaya matahari pada saat penelitian bisa menjadi faktor lain yang mendukung pertumbuhan tanaman tomat. Perlakuan Pc dapat penempatan sistem RAL mendapatkan cahaya matahari paling lama dibanding perlakuan yang lain.

\subsubsection{Varian Pemberian Pupuk Yang Paling Efektif}

Dari hasil pengamatan pertumbuhan tinggi tanaman tomat selama 3 minggu, selisih tinggi cenderung kecil namun tetap signifikan. Setelah dilakukan uji antar treatment untuk menentukan varian perlakuan mana yang paling eefektif, peneliti menyimpulkan bahwa $\mathrm{Pb}$ adalah varian pupuk yang paling efektif. Karena dengan selisih tinggi yang kecil namun penggunaan bahan pupuk yang efisien yaitu 150 gram untuk $1 \mathrm{~kg}$ media tanam. Adapun komposisi pupuk pada perlakuan $\mathrm{Pb}$ yaitu ampas kopi sebesar 200 gram dan ampas kelapa 200 gram.

\section{KESIMPULAN DAN SARAN}

\subsection{Kesimpulan}

Berdasarkan hasil penelitian yang telah dilakukan dapat disimpulkan bahwa:

a. Kadar N, P dan K pada pupuk organik sebesar :

- Pada pupuk A dengan kadar ampas kelapa 200 gram mengandung $1,104 \% \mathrm{~N}, 1,741$ $\% \mathrm{P}, 1,19 \% \mathrm{~K}$ dan $\mathrm{C} / \mathrm{N} 25,612$.

- Pada pupuk B dengan kadar ampas kelapa 300 gram mengandung $1,050 \% \mathrm{~N}, 1,850$ $\% \mathrm{P}, 1,155 \% \mathrm{~K}$ dan $\mathrm{C} / \mathrm{N} 25,513$.

Datadiatas menunjukkan bahwa pupuk organik belum memenuhi syarat pupuk organik padat yang tercantum dalam PERMENTAN NO.70 Tahun 2011.

b. Penambahan pupuk organik dari ampas kopi dan ampas kelapa pada media tanam dapat berpengaruh nyata terhadap pertumbuhan tinggi tanaman tomat. Untuk parameter tinggi tanaman teleh terbukti bahwa $\mathrm{F}$ Hitung 79,893 > F Tabel 2,85 pada pengamatan tinggi tanaman setiap minggunya.

c. Varian pemberian pupuk organik dari ampas kopi dan ampas kelapa paling efektif adalah perlakuan $\mathrm{Pb}$ dengan pemberian 150 gram pupuk pada media tanam $1 \mathrm{~kg}$.

\subsection{Saran}

Berdasarkan penelitian yang dilakukan, dikemukakan saran yaitu :

a. Perlu dilakukan lagi penelitian untuk penambahan komposisi ampas kelapa pada bahan pembuatan pupuk agar terlihat 
perbedaan kualitas pupuk organik yang dihasilkan.

b. Agar memperhatikan intensitas cahaya yang mengenai tanaman agar semua perlakuan bisa mendapat cahaya matahari yang sama.

c. Pengamatan yang lebih detail pada pertumbuhan tanaman dengan menambahkan jumlah daun, diameter batang, panjang tangkai sebagai analisa.

Perlu dilakukan perhitungan ekonomi mengenai hasil pupuk organik dari ampas kopi dan ampas kelapa.

\section{DAFTAR PUSTAKA}

Adikasari, Ria. 2012, Pemanfaatan Ampas Teh dan Ampas Kopi Sebagai Penambah Nutrisi Pada Pertumbuhan Tanaman. Skripsi. FKIP,Universitas Muhammadiyah Surakarta.

Balai Penelitian dan Pengembangan Pertanian, Balai Pengkajian Teknologi Pertanian (BPTP) Yogyakarta 2011. Pembuatan Pupuk Organik dan Penggunaannya pada Tumpangsari Bawang Merah dan Cabe Merah, Yogyakarta.

Falahuddin, Irham, Raharjeng, Anita Restu Puji, Harmeni, Lekat. 2016. Pengaruh Pupuk Organik Limbah Kulit Kopi (Coffea Arabica L.) Terhadap Pertumbuhan Bibit Kopi. Jurnal Biolmi.
UIN Raden Fatah Palembang.

http://kambingjoynim.com/caramembuat-pupuk-kandangdari-kotoran-sapi-denganem4 (1/5/2017-11.30)

Makiyah, Mujiatul. 2013. Analisis Kadar N, P dan K Pada Pupuk Cair Limbah Tahu Dengan Penambahan Tanaman Matahari Meksiko (Thitonia diversivolia). Skripsi. Fakultas Matematika dan Ilmu Pengetahuan Alam. Universitas Negeri Semarang.

Najiyati, Sri, Danarti, 1990. Kopi Budidaya dan Penanganan Lepas Panen. Penebar Swadaya. Yogyakarta.

Pemerintah Republik Indonesia, Peraturan Menteri Pertanian Nomor : 70/Permentan/SR.140/10/20 11 Tentang Pupuk Organik, Pupuk Hayati dan Pembenah Tanah. Jakarta.

Roidah, Syamsu Ida, 2013. Manfaat Penggunaan Pupuk Organik Untuk Kesuburuan Tanah. Jurnal Universitas Tulungagung. BONOROWO.

Sari, Iis Mita. 2015, Pengaruh Media dengan Penambahan Ampas Kelapa Terhadap Pertumbuhan dan Perkembangan Jamur Tiram Putih (Pleurotus ostreatus) dan Sumbangsihnya 
terhadap Mata Pelajaran

Biologi SMA Kelas X

Semester I Materi Fungi. Skripsi. Fakultas Tarbiyah dan Keguruan, Universitas Islam Negeri Raden Fatah Palembang.

Suhardiman, P. 1991. Bertanam Kelapa Hibrida. Penebar Swadaya. Yogyakarta. 